\title{
Mechanical and tribological behavior of silicon nitride and silicon carbon nitride coatings for total joint replacements
}

\author{
M Pettersson, S Tkachenko, Susann Schmidt, Torun Berlind, S Jacobson, Lars Hultman, H
}

Engqvist and C Persson

\section{Linköping University Post Print}

\section{Tweet}

N.B.: When citing this work, cite the original article.

Original Publication:

M Pettersson, S Tkachenko, Susann Schmidt, Torun Berlind, S Jacobson, Lars Hultman, H Engqvist and C Persson, Mechanical and tribological behavior of silicon nitride and silicon carbon nitride coatings for total joint replacements, 2013, Journal of The Mechanical Behavior of Biomedical Materials, (25), 41-47.

http://dx.doi.org/10.1016/j.jmbbm.2013.05.002

Copyright: Elsevier

http://www.elsevier.com/

Postprint available at: Linköping University Electronic Press

http://urn.kb.se/resolve?urn=urn:nbn:se:liu:diva-95932 


\title{
Mechanical and tribological behavior of silicon nitride and silicon carbon nitride coatings for total joint replacements
}

\author{
M. Pettersson ${ }^{a}$, S. Tkachenko ${ }^{a}$, S. Schmidt ${ }^{b}$, T Berlind ${ }^{b}$, S. Jacobson ${ }^{a}$, L. Hultman $^{b}$, \\ H. Engqvist ${ }^{a}$ and C. Persson ${ }^{a}$ \\ ${ }^{a}$ Applied Materials Science, Department of Engineering Sciences, Uppsala University, \\ Ångström Laboratory, 75121 Uppsala, Sweden. \\ ${ }^{b}$ Thin Film Physics, Department of Physics, Chemistry and Biology (IFM), Linköping University, \\ 58183 Linköping, Sweden.
}

\begin{abstract}
Total joint replacements currently have relatively high success rates at 10-15 years, however increasing ageing and an active population places higher demands on the longevity of the implants. A wear resistant configuration with wear particles that resorb in vivo can potentially increase the lifetime of an implant. In this study, silicon nitride $\left(\mathrm{Si}_{\mathrm{x}} \mathrm{N}_{\mathrm{y}}\right)$ and silicon carbon nitride $\left(\mathrm{Si}_{\mathrm{x}} \mathrm{C}_{\mathrm{y}} \mathrm{N}_{\mathrm{z}}\right)$ coatings were produced for this purpose using reactive high power impulse magnetron sputtering (HiPIMS). The coatings are intended for hard bearing surfaces on implants. Hardness and elastic modulus of the coatings were evaluated by nanoindentation, cohesive, and adhesive properties were assessed by micro scratching and the tribological performance was investigated in a ball-on-disc setup run in a serum solution. The majority of the $\mathrm{Si}_{\mathrm{x}} \mathrm{N}_{\mathrm{y}}$ coatings showed a hardness close to that of sintered silicon nitride ( 18 GPa), and an elastic modulus close to that of cobalt chromium ( 200 GPa). Furthermore, all except one of the $\mathrm{Si}_{\mathrm{x}} \mathrm{N}_{\mathrm{y}}$ coatings offered a wear resistance similar to that of bulk silicon nitride and significantly higher than that of cobalt chromium. In contrast, the $\mathrm{Si}_{\mathrm{x}} \mathrm{C}_{\mathrm{y}} \mathrm{N}_{\mathrm{z}}$ coatings did not show as high level of wear resistance.
\end{abstract}

Keywords: silicon nitride, silicon carbon nitride, coatings, total joint replacements, biotribology.

*Corresponding author: Maria Pettersson (maria.pettersson@angstrom.uu.se). 
1.

Introduction

Total joint replacements have relatively high success rates at 10-15 years (Garellick et al., 2011). However, as the population gets older and more active, higher demands are placed on the implants. Several types of bearing couples are used in hip replacements, such as metal-on-polymer, metal-onmetal, ceramic-on-ceramic, and ceramic-on-metal. The metal-on-polymer bearing is the most common configuration, using cobalt chromium alloy ( $\mathrm{CoCr}$ ) on ultra-high molecular weight polyethylene (UHMWPE). However, wear particles from UHMWPE may induce an inflammatory reaction, which may lead to bone resorption and loosening of the implant (Ingham and Fisher, 2005). The release of metal ions is also a reason for concern due to toxicity (Sargeant and Goswami, 2007). Furthermore, a risk of catastrophic failure arises when bulk ceramics are used, due to their brittleness. In order to avoid this, the ceramic can be used as a coating on a more ductile (metal) substrate. Advantages with coatings can include reduced wear rates and an increased corrosion resistance (Lappalainen and Santavirta, 2005). A reduced amount of metal ion release would naturally be of great interest. Different surface treatments and coatings have been investigated for the bearing surfaces between the femoral head and the acetabular cup in hip implants, such as TiN (Harman et al., 1997; Pappas et al., 1995; Teresa Raimondi and Pietrabissa, 2000), diamond-like carbon (Affatato et al., 2000; Fisher et al., 2002; Lappalainen et al., 1998), $\mathrm{CrN}$ (Fisher et al., (2002), CrCN (Fisher et al., 2002), $\mathrm{ZrO}_{2}$ (Yen et al., 2001), and $\mathrm{Al}_{2} \mathrm{O}_{3}$ (Yen and Hsu, 2001). However, insufficient adhesion and coating artifacts, such as droplets, have been reported as major concerns for these coatings.

During the last decades silicon nitride has been investigated for and introduced into the biomedical field. Traditionally, it has been used in engines, cutting tools, and ball bearings for its high mechanical performance (Riley, 2000). Today, silicon nitride is used for spinal implants and in early 2011 the first silicon nitride femoral head was implanted in USA. The choice of silicon nitride as an implant material is motivated by its excellent biocompatibility, low wear rates as well as relatively high fracture toughness and strength (Mazzocchi and Bellosi, 2008; Mazzocchi et al., 2008; $\underline{\text { Sonny Bal et }}$ al., 2008, 2009). 
Furthermore, silicon nitride particles dissolve in aqueous media (Laarz et al., 2000). This, in turn, suggests that wear particles can dissolve in vivo, which may reduce the negative body response from the debris, and potentially increase the longevity of the implant. Additionally, density functional theory (DFT) calculations have shown that small amounts of substitutionally-bonded carbon can destabilize crystalline $\mathrm{Si}_{3} \mathrm{~N}_{4}$, indicating the possibility to tune the dissolution rate (Olofsson et al., 2012). To this date, there have only been a few publications on silicon nitride $\left(\operatorname{Si}_{x} N_{y}\right)$ and silicon carbon nitride $\left(\mathrm{Si}_{\mathrm{x}} \mathrm{C}_{\mathrm{y}} \mathrm{N}_{\mathrm{z}}\right.$ ) coatings for joint implants (Olofsson et al., 2012; Shi et al., 2011, 2012). Olofsson et al. (2012) used reactive radio frequency (r.f.) sputtering to produce $\mathrm{Si}_{\mathrm{x}} \mathrm{N}_{\mathrm{y}}$ and $\mathrm{Si}_{\mathrm{x}} \mathrm{C}_{\mathrm{y}} \mathrm{N}_{\mathrm{z}}$ coatings that showed a potential for high wear resistance, but issues with coating defects and poor adhesion leading to flaking off of the coatings were reported. Shi et al. (2011) also used different magnetron sputtering methods for fabricating $\mathrm{Si}_{x} \mathrm{~N}_{\mathrm{y}}$ and $\mathrm{Si}_{\mathrm{x}} \mathrm{C}_{\mathrm{y}} \mathrm{N}_{\mathrm{z}}$ coatings; r.f., direct current and unbalanced magnetron sputtering. However, adhesive properties of the coating were not reported.

In this study, $\mathrm{Si}_{\mathrm{x}} \mathrm{N}_{\mathrm{y}}$ and $\mathrm{Si}_{\mathrm{x}} \mathrm{C}_{\mathrm{y}} \mathrm{N}_{\mathrm{z}}$ coatings were deposited using high power impulse magnetron sputtering (HiPIMS). Owing to high plasma densities and increased ionization probabilities, HiPIMS has been reported to produce dense coatings on complex structures (Alami et al., 2005). In addition, HiPIMS can be used to obtain increased adhesion between coating and its substrate (Sarakinos et al., 2010). In order to assess the mechanical properties and the durability of the coatings, hardness and elastic modulus were studied by nanoindentation, while cohesive and adhesive failure were investigated with micro scratching. The tribological properties, friction and wear resistance were studied in a ball-on-disc setup.

2.

Materials and Methods

2.1.

Coating deposition

Conventional P-doped Si (001) (Semiconductor Wafer, Inc) was used as substrate material for all coatings, due to its availability and the preliminary nature of the study. Additionally, three of the coatings were deposited on cobalt chromium (CoCr, ASTM F75, Sandvik AB, Sweden). The substrates were cleaned in 5 min sequences, first in acetone then in ethanol, and dried in $\mathrm{N}_{2}$ gas before 
deposition. The coatings were deposited using the industrial coating system CC800/9 ML (CemeCon, Germany) with rectangular targets $(50 \times 8.8 \mathrm{~cm})$. The deposition process took place in power controlled HiPIMS mode using a pulse width of $200 \mu \mathrm{s}$, at a frequency of $300 \mathrm{~Hz}$. The reactive sputter process was carried out with an $\mathrm{Ar} / \mathrm{N}_{2}$-flow ratio of 0.16 . For the $\mathrm{Si}_{\mathrm{x}} \mathrm{N}_{\mathrm{y}}$ coatings, a silicon target (purity 99.999\%) was used. During the deposition process the substrates faced the target at a distance of $6 \mathrm{~cm} . \mathrm{Si}_{\mathrm{x}} \mathrm{C}_{\mathrm{y}} \mathrm{N}_{\mathrm{z}}$ coatings were produced by co-sputtering from a silicon target and a graphite target (purity 99.5\%). Here, the samples were rotated to pass both targets at the same target-to-substrate distance as for the $\mathrm{Si}_{\mathrm{x}} \mathrm{N}_{\mathrm{y}}$ coatings. This sample rotation causes the formation of Si- and C-monolayers with a thickness below $10 \mathrm{~nm}$. A negative bias voltage of $-100 \mathrm{~V}$ was applied during the deposition. No pre-sputtering of the substrate was performed before the coating deposition. In order to alter the composition of the coatings, the following parameters were varied; the substrate temperature $\left(110^{\circ} \mathrm{C}\right.$, hereinafter denoted ' $l$ ' for low, and $430{ }^{\circ} \mathrm{C}$, denoted ' $h$ ' for high), the Si target power (1-4 kW), Ctarget power (0-1.4 kW or absent for $\mathrm{Si}_{\mathrm{x}} \mathrm{N}_{\mathrm{y}}$ coatings), as well as a stationary deposition for $\mathrm{Si}_{\mathrm{x}} \mathrm{N}_{\mathrm{y}}$ coatings and sample rotation for $\mathrm{Si}_{\mathrm{x}} \mathrm{C}_{\mathrm{y}} \mathrm{N}_{\mathrm{z}}$ coatings. Hence, the coatings are referred to using these variations, for example $\operatorname{SiCN}(4 / 0.5 / h)$ intend a $\mathrm{Si}_{x} \mathrm{C}_{\mathrm{y}} \mathrm{N}_{\mathrm{z}}$ coating deposited with a Si target power of $4 \mathrm{~kW}$, a C target power of $0.5 \mathrm{~kW}$ and a substrate temperature of $430^{\circ} \mathrm{C}$. When no C-target was used, this is indicated by '-', e.g. $\mathrm{SiN}(1 /-/ l)$, which is a $\mathrm{Si}_{\mathrm{x}} \mathrm{N}_{\mathrm{y}}$ coating deposited at a silicon target power of 1 $\mathrm{kW}$, with no C-target and a substrate temperature of $110^{\circ} \mathrm{C}$. The C content was estimated by energy dispersive spectroscopy analysis (EDS, EDAX Microanalysis, Netherlands) integrated in a scanning electron microscopy (SEM), at an acceleration voltage of $5 \mathrm{kV}$ to obtain a surface sensitive measurement. The stationary deposited $\mathrm{Si}_{\mathrm{x}} \mathrm{N}_{\mathrm{y}}$ coatings were thicker $(1.2-4.4 \mu \mathrm{m})$ than the $\mathrm{Si}_{\mathrm{x}} \mathrm{C}_{\mathrm{y}} \mathrm{N}_{\mathrm{z}}$ coatings $(0.4-0.9 \mu \mathrm{m})$.

\subsection{Mechanical characterization}

Two bulk materials were used as references: CoCr (ASTM F75, Sandvik AB, Sweden, $\mathrm{R}_{\mathrm{a}} \sim 8 \mathrm{~nm}$ ) and $\mathrm{Si}_{3} \mathrm{~N}_{4}$ (Keranova $\mathrm{AB}$, Sweden, $\mathrm{R}_{\mathrm{a}} \sim 15 \mathrm{~nm}$ ). Hardness and elastic modulus of the reference materials and the coatings were obtained using a commercial nanoindenter (CSM Instruments UNHT, Switzerland) with a Berkovich tip. A total of 30 indents per sample were completed varying the 
maximum load to obtain an approximate indentation depth of $40 \mathrm{~nm}$. Hardness and elastic modulus were calculated using the Oliver-Pharr method (Oliver and Pharr, 1992). The elastic modulus was determined for the coatings and for the reference $\mathrm{Si}_{3} \mathrm{~N}_{4}$ using a Poisson's ratio of 0.25 (Walmsley et al., 2007), whereas for CoCr a Poisson's ratio of 0.3 was assumed.

Scratch tests were performed using a micro scratcher (CSM Instruments UNHT, Switzerland) with a sphero-conical stylus (apex $90^{\circ}$; tip radius $2 \mu \mathrm{m}$ ). A progressive load up to $300 \mathrm{mN}$ over $600 \mu \mathrm{m}$ (loading rate $150 \mathrm{mN} / \mathrm{min}$ ) was applied. Additional pre- and post-scans were carried out with a load of $3 \mathrm{mN}$ in the same direction. Critical loads $\mathrm{L}_{\mathrm{C} 1}$ and $\mathrm{L}_{\mathrm{C} 2}$, indicating the onset of cohesive and adhesive failure of the coatings, respectively, were determined using load vs. depth profiles in combination with optical and SEM (LEO 440, Zeiss, Germany).

Wear tests in a ball-on-disc equipment were conducted based on ASTM F 732-00 (2006). The samples were tested against a $\mathrm{Si}_{3} \mathrm{~N}_{4}$-ball (6 $\mathrm{mm}$ in diameter, Spekuma, Sweden), to simulate the coating sliding against itself. The disc specimen was rotated at a speed of $0.04 \mathrm{~m} / \mathrm{s}$ applying a normal load of $1 \mathrm{~N}$, forming a wear track of $5 \mathrm{~mm}$ in diameter. Due to differences in wear performance, tests were run for 1000 and 10000 revolutions, for $\mathrm{Si}_{\mathrm{x}} \mathrm{C}_{\mathrm{y}} \mathrm{N}_{\mathrm{z}}$ and $\mathrm{Si}_{\mathrm{x}} \mathrm{N}_{\mathrm{y}}$ coatings, respectively. In order to simulate physiological conditions, the wear tests were run in a serum solution of $25 \%$ fetal bovine serum (Gibco, EU approved, origin South America) with sodium azide (Sigma-Aldrich, St Louis, USA) and ethylene-diaminetetraacetic acid (EDTA, Sigma-Aldrich, St Louis, USA) as specified in the standard ASTM F 732-00 (2006). The wear rate was quantified using the specific wear rate according to Archard's wear equation (Archard, 1953):

Specific wear rate $=\frac{\text { Wear volume }}{\text { Load } \cdot \text { Sliding distance }}$. 
The wear rate, excluding the ball, was calculated from the worn cross-sectional area, measured with vertical scanning interferometry (VSI, Wyko NT-1100, Vecco, USA). VSI was also used to determine surface roughness $\left(\mathrm{R}_{\mathrm{a}}\right)$.

\section{Results}

The relative C concentration was estimated using EDS, and was found to increase with increasing Ctarget power and decreasing power on the Si target, as shown in Table 1 . The $\mathrm{C}$ concentration did not appear to be affected by the different deposition temperatures.

3.1. $\quad$ Hardness and elastic modulus

The hardness and elastic modulus are displayed in Fig. 1, and the hardness to elastic modulus ratio (H/E) is specified in Table 1. All coatings were found to be harder than CoCr but softer than bulk $\mathrm{Si}_{3} \mathrm{~N}_{4}$. Generally, the $\mathrm{Si}_{\mathrm{x}} \mathrm{N}_{\mathrm{y}}$ coatings were harder than the $\mathrm{Si}_{\mathrm{x}} \mathrm{C}_{\mathrm{y}} \mathrm{N}_{\mathrm{z}}$ coatings. Very similar hardness values of the coatings were recorded on both substrates ( $\mathrm{Si}$ or $\mathrm{CoCr}$ ), Fig 1, confirming that there was no influence from the substrate in the hardness and elastic modulus measurements.

\subsection{Micro scratching}

The micro scratching revealed adhesive failure for the $\mathrm{Si}_{\mathrm{x}} \mathrm{N}_{\mathrm{y}}$ coatings at loads above $214 \mathrm{mN}$, and coatings SiN (3/-/l), (4/-/l), and (3/-/h) resisted loads up to the maximum $300 \mathrm{mN}$ without any rupture, see Table 1 . The adhesive failure of $\mathrm{Si}_{\mathrm{x}} \mathrm{N}_{\mathrm{y}}$ coatings occurred by extensive flaking in front of and behind the scratching tip, Fig. 2a and b. The deformation and redistribution of the material before failure for all $\mathrm{Si}_{\mathrm{x}} \mathrm{N}_{\mathrm{y}}$ coatings, except $\mathrm{SiN}$ (1/-/l), was accompanied by the formation of micro cracks on the ridges, Fig. 2a. The SiN (1/-/l) coating deformed without visible micro cracking up to final failure, Fig. 2b. Cohesive failure of the $\mathrm{Si}_{\mathrm{x}} \mathrm{C}_{\mathrm{y}} \mathrm{N}_{\mathrm{z}}$ coatings occurred at loads around $50 \mathrm{mN}$ and adhesive failure below $105 \mathrm{mN}$. Coatings deposited with higher Si target power (4 kW) showed cohesive failure by flaking (Fig. 2c), while coatings deposited at the lower target power (1 kW) showed cohesive failure by transverse cracks (Fig. 2d), both followed by adhesive failure of the coating. $\mathrm{Si}_{\mathrm{x}} \mathrm{C}_{\mathrm{y}} \mathrm{N}_{\mathrm{z}}$ 
coatings deposited on CoCr showed half the cohesive and adhesive failure loads of those deposited on Si-wafers.

\subsection{Friction and wear}

The $\mathrm{Si}_{\mathrm{x}} \mathrm{N}_{\mathrm{y}}$ coatings showed a stable friction coefficient between 0.2 and 0.3 over 10000 revolutions, see Fig. 3. An exception was $\operatorname{SiN}(4 /-/ l)$, which had a drastic friction increase in the beginning and later reached a stable friction coefficient of 0.33 . Both reference materials showed a lower friction coefficient than the $\mathrm{Si}_{\mathrm{x}} \mathrm{N}_{\mathrm{y}}$ coatings. Cross-section profiles of the wear tracks on the $\mathrm{Si}_{\mathrm{x}} \mathrm{N}_{\mathrm{y}}$ coating, sintered $\mathrm{Si}_{3} \mathrm{~N}_{4}$ and $\mathrm{CoCr}$, from which the wear rates were calculated, are demonstrated in Fig. 4. The SiN (4/-/l) coating wore down to a depth of $2 \mu \mathrm{m}$ and is not shown in the figure. With respect to CoCr, the $\mathrm{Si}_{\mathrm{x}} \mathrm{N}_{\mathrm{y}}$ coatings, except $\mathrm{SiN}(4 /-/ l)$, showed a much higher wear resistance, similar to that of $\mathrm{Si}_{3} \mathrm{~N}_{4}$. Examples of the wear tracks are displayed in Fig. 5 and specific wear rates are given in Table 1. The $\mathrm{Si}_{\mathrm{x}} \mathrm{C}_{\mathrm{y}} \mathrm{N}_{\mathrm{z}}$ coatings were tested for 1000 revolutions in the ball-on-disc tests, as previously mentioned. The majority of these coatings were worn through and failed during the test. The lowest wear rate of the $\mathrm{Si}_{\mathrm{x}} \mathrm{C}_{\mathrm{y}} \mathrm{N}_{\mathrm{z}}$ coatings was $100 \times 10^{-7} \mathrm{~mm}^{3} / \mathrm{N} \mathrm{m}$, obtained for $\operatorname{SiCN}(1 / 1.4 / l)$.

\section{Discussion}

In this study, $\mathrm{Si}_{\mathrm{x}} \mathrm{N}_{\mathrm{y}}$ and $\mathrm{Si}_{\mathrm{x}} \mathrm{C}_{\mathrm{y}} \mathrm{N}_{\mathrm{z}}$ coatings were produced using HiPIMS and evaluated in terms of mechanical properties using nanoindentation (for hardness and elastic modulus), micro scratching (for cohesive and adhesive properties), and in a ball-on-disc setup (for friction and wear properties). The amount of $\mathrm{C}$ in the coatings was analyzed by EDS. However, these $\mathrm{C}$ concentrations should be interpreted as relative concentrations within this study, rather than absolute quantitative values. This caution is necessary since no standard was used for calibration of the measurements, and EDS has limitations in detecting light elements. Despite this, the values presented can be used for relative comparisons within the study and the $\mathrm{C}$ concentrations correlate well with what was expected from the deposition rates from the targets. 
An electron flight simulation based on a Monte Carlo model was performed assuming an acceleration voltage of $5 \mathrm{kV}$ in $\mathrm{Si}_{3} \mathrm{~N}_{4}$ and estimated the maximum information depth to $0.3 \mu \mathrm{m}$. Also, the absence of $\mathrm{Co}$, $\mathrm{Cr}$ and Mo signals in the EDS analysis of coatings deposited on CoCr, confirms that the chemical information was obtained from the coating only.

For hip joints there is a risk that wear particles or bone cement particles become trapped in the contact and cause abrasion (Bragdon et al., 2003; Dowling et al., 1978 ; Wang and Essner, 2001). A higher hardness of the joint bearing surfaces could therefore be an advantage by increasing the resistance to two and three body abrasive wear. The $\mathrm{Si}_{\mathrm{x}} \mathrm{N}_{\mathrm{y}}$ coatings were found to possess a high hardness, up to 21 $\mathrm{GPa}$, while the hardness of some of the $\mathrm{Si}_{x} \mathrm{C}_{\mathrm{y}} \mathrm{N}_{\mathrm{z}}$ coatings were half of that. These variation are likely caused by the chemical and microstructural differences between the two types of coatings, caused by the $C$ content and the layered structure (from the sample rotation, see section 2.1) of the $\mathrm{Si}_{\mathrm{x}} \mathrm{C}_{\mathrm{y}} \mathrm{N}_{\mathrm{z}}$ coatings. The hardness and elastic modulus of the $\mathrm{Si}_{\mathrm{x}} \mathrm{N}_{\mathrm{y}}$ and $\mathrm{Si}_{\mathrm{x}} \mathrm{C}_{\mathrm{y}} \mathrm{N}_{\mathrm{z}}$ coatings (especially for coatings with a low C content) was similar to literature data for coatings deposited using different sputtering methods (DC, r.f. and HiPIMS) (Olofsson et al., 2012; Pusch et al., 2011; Shi et al., 2012). For the $\mathrm{Si}_{\mathrm{x}} \mathrm{N}_{\mathrm{y}}$ coatings, a lower $\mathrm{Si}$ target power resulted in harder coatings, while no dependence of the deposition temperature was evident. The relation is probably linked to chemical differences between the $\mathrm{Si}_{\mathrm{x}} \mathrm{N}_{\mathrm{y}}$ coatings. These trends did not apply to the $\mathrm{Si}_{\mathrm{x}} \mathrm{C}_{\mathrm{y}} \mathrm{N}_{\mathrm{z}}$ coatings. The reason for a lower hardness and elastic modulus for SiCN (1/0.7-1.4/l) is not yet fully understood. The difference in deposition temperature possibly affects the morphology, microstructure and/or chemistry in the coating and will be further investigated in a follow up study. The elastic moduli of the majority of the coatings were similar to that of $\mathrm{CoCr}$, except $\mathrm{SiCN}$ (1/0.7-1.4/l), as discussed above.

The coatings differed in thickness, consequently the failure loads $\left(\mathrm{L}_{\mathrm{c} 1}\right.$ and $\left.\mathrm{L}_{\mathrm{c} 2}\right)$ were not compared. However, the modes of failure in micro scratching were found to correlate with the wear properties. For the $\mathrm{Si}_{\mathrm{x}} \mathrm{N}_{\mathrm{y}}$ coatings, the wear resistance appeared to relate to the ability to avoid micro cracks before adhesive failure. The SEM analysis showed that no micro cracks were formed before failure for SiN (1/-/l) in Fig. 2b, (compare with Fig. 2a). This coating also showed the highest hardness, i.e. the 
best ability to resist plastic deformation. A more brittle fracture can be seen for the harder SiN coatings in Fig. 2a and b, compared to the more ductile behavior seen for SiCN coatings in Fig. 2c and d. SiN (1/-/l) also showed the lowest wear rates and the highest H/E ratio. Leyland described the H/E ratio as a better way of predicting wear performance than hardness or elastic modulus individually (Leyland and Matthews, 2000). This approach predicts the poor wear performance for CoCr, but shows no trend for the remaining samples. The cohesive failure types for $\mathrm{Si}_{\mathrm{x}} \mathrm{C}_{\mathrm{y}} \mathrm{N}_{\mathrm{z}}$ coatings, cracks and flakes, are believed to be related to different microstructures of the coatings, caused by deposition at different Si target powers. A higher Si target power is hypothesized to give a laminar structure and a lower power a columnar structure, since failure of a laminar structure appears between the lamellas, whereas for a columnar structure the failure arises between the columns. This may be a drawback for the $\mathrm{Si}_{\mathrm{x}} \mathrm{C}_{\mathrm{y}} \mathrm{N}_{\mathrm{z}}$ coating, since weaker parts in the coatings risk a non-homogenously distributed failure through the coating, which can be hard to predict. When coatings were deposited on $\mathrm{CoCr}$, the failure loads were only half of those on Si-wafers, which indicates that further optimization of the coating adhesion to CoCr is possible.

It is not yet completely understood why coating $\mathrm{SiN}(4 /-/ l)$ differs from the remaining $\mathrm{Si}_{\mathrm{x}} \mathrm{N}_{\mathrm{y}}$ coatings in the wear test. The high wear rate is most likely related to the initially higher friction and possibly also the lower hardness, causing a larger contact area in the wear test. Neither could the low wear resistance of $\mathrm{Si}_{\mathrm{x}} \mathrm{C}_{\mathrm{y}} \mathrm{N}_{\mathrm{z}}$ coatings be fully explained. Coatings $\mathrm{SiN}$ (1 to 3/-/l) and (2 to 3/-/h) displayed notably lower wear rates than the other coatings. The rates were close to $\mathrm{Si}_{3} \mathrm{~N}_{4}$-on- $\mathrm{Si}_{3} \mathrm{~N}_{4}$. In comparison with similar studies, the $\mathrm{Si}_{\mathrm{x}} \mathrm{N}_{\mathrm{y}}$ coatings matched the wear rates of $\mathrm{Si}_{3} \mathrm{~N}_{4}$-TiN-compositeon- $\mathrm{Al}_{2} \mathrm{O}_{3}$ (Mazzocchi et al., 2008), CrN-on-CrN and CrCN-on-CrCN, and performed better than TiNon-TiN and CoCr-on-CoCr (Williams et al., 2003), and were also superior to most CoCr-on-

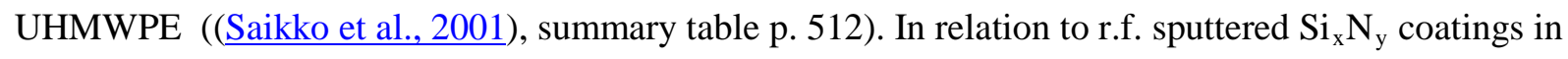
a study by (Olofsson et al., 2012), the wear rates with the HiPIMS deposited $\mathrm{Si}_{\mathrm{x}} \mathrm{N}_{\mathrm{y}}$ coatings had similar to slightly lower wear rates, although the friction were somewhat higher in this study. Coatings deposited at lower Si target power had a slightly lower wear rate, these coatings also show the highest hardness, as discussed. Note that additional parameters to those in Eq. 1 can affect the wear (for 
example surface roughness), therefor caution needs to be taken when making direct comparisons with other studies. Future work should focus on understanding not only the wear but also the wear particles, since dissolution of wear particles may reduce a possible negative body response. The amount, size, shape, composition, bonding structure of the particles as well as $\mathrm{pH}$ etc. could affect the dissolution rate. The dissolution rate needs to be tuned so that the wear particles can dissolve but not the coating to a high extent.

The test configuration with a ceramic ball sliding against the various coatings was used in order to simulate $\mathrm{Si}_{\mathrm{x}} \mathrm{N}_{\mathrm{y}}$ or $\mathrm{Si}_{\mathrm{x}} \mathrm{C}_{\mathrm{y}} \mathrm{N}_{\mathrm{z}}$ coatings wearing against themselves. The most common in vivo configuration for $\mathrm{CoCr}$ is towards UHMWPE, where the majority of material loss occurs on the polymer. This is in contrast to the tested configuration $\mathrm{Si}_{3} \mathrm{~N}_{4}$-on-CoCr, where mainly the CoCr was worn. However, the model test can relate the coatings wear resistance in to $\mathrm{Si}_{3} \mathrm{~N}_{4}$-on- $\mathrm{Si}_{3} \mathrm{~N}_{4}$ and $\mathrm{Si}_{3} \mathrm{~N}_{4}$-on-CoCr.

An initial study of using $\mathrm{Si}_{\mathrm{x}} \mathrm{N}_{\mathrm{y}}$ and $\mathrm{Si}_{\mathrm{x}} \mathrm{C}_{\mathrm{y}} \mathrm{N}_{\mathrm{z}}$ for joint replacements was performed, motivated by previous DFT calculations. However, further development and investigations are needed. Wear studies were made in model tests comparing the coatings among each other and in relation to present materials for the specific application, future wear tests should include hip or knee simulator studies. In order to approach the application, an understanding of the structure and chemistry of the coatings has to be acquired along with the biological response both to the coating, wear particles, and the lubrication around the implant. As for the bearing surface of joint replacements a thickness of tenths of micrometers is needed, for this, excellent coating adhesion is required and needs, thus further investigations. Nevertheless, this initial promising result motivates further work on $\mathrm{Si}_{\mathrm{x}} \mathrm{N}_{\mathrm{y}}$ and $\mathrm{Si}_{\mathrm{x}} \mathrm{C}_{\mathrm{y}} \mathrm{N}_{\mathrm{z}}$ for joint replacements.

\section{Conclusions}

$\mathrm{Si}_{\mathrm{x}} \mathrm{N}_{\mathrm{y}}$ and $\mathrm{Si}_{\mathrm{x}} \mathrm{C}_{\mathrm{y}} \mathrm{N}_{\mathrm{z}}$ coatings have been deposited using HiPIMS in order to explore a wear resistant alternative for bearing surfaces in total joint replacements. The coatings showed hardness ranging 
from that of sintered $\mathrm{Si}_{3} \mathrm{~N}_{4}$ to CoCr. The elastic modulus of the majority of $\mathrm{Si}_{\mathrm{x}} \mathrm{N}_{\mathrm{y}}$ and $\mathrm{Si}_{\mathrm{x}} \mathrm{C}_{\mathrm{y}} \mathrm{N}_{\mathrm{z}}$ coatings were similar to that of CoCr. The wear resistance of all of the $\mathrm{Si}_{\mathrm{x}} \mathrm{N}_{\mathrm{y}}$ coatings except one was in a range similar to that of sintered $\mathrm{Si}_{3} \mathrm{~N}_{4}$ and significantly higher than that of CoCr. This promising mechanical property may be explained by the coating's ability to avoid cohesive cracks. None of the $\mathrm{Si}_{\mathrm{x}} \mathrm{C}_{\mathrm{y}} \mathrm{N}_{\mathrm{z}}$ coatings showed wear resistance matching that of $\mathrm{Si}_{3} \mathrm{~N}_{4}$ or the $\mathrm{Si}_{\mathrm{x}} \mathrm{N}_{\mathrm{y}}$ coatings under the tested conditions. Also, there is room for process optimization to increase the adhesion to $\mathrm{CoCr}$ substrates.

In conclusion, $\mathrm{Si}_{\mathrm{x}} \mathrm{N}_{\mathrm{y}}$ coatings are of great interest for further studies because of their combination of hardness, elastic modulus, and wear resistance. In particular the SiN (1/-/l) coating, which exhibited the highest hardness (21 GPa), one of the higher elastic moduli (212 GPa), the lowest wear rate (1.3 • $10^{-7} \mathrm{~mm}^{3} / \mathrm{Nm}$ ) and also fractured in a homogenous way in the scratch test.

\section{Acknowledgements}

The authors are grateful for the financial support from the Swedish Foundation for Strategic Research (SSF) through the program in Materials for Nanoscale Surface Engineering (MS²E), as well as VINNOVA and the Swedish Institute.

\section{References}

Affatato, S., Frigo, M., Toni, A., 2000. An in vitro investigation of diamond-like carbon as a femoral head coating. Journal of Biomedical Materials Research 53(3), 221-226.

Alami, J., Persson, P.O.A., Music, D., Gudmundsson, J.T., Bohlmark, J., Helmersson, U., 2005. Ionassisted physical vapor deposition for enhanced film properties on nonflat surfaces. Journal of Vacuum Science \& Technology A: Vacuum, Surfaces, and Films 23(2), 278-280.

Archard, J.F., 1953. Contact and Rubbing of Flat Surfaces. Journal of Applied Physics 24(8), 981-988.

Bragdon, C.R., Jasty, M., Muratoglu, O.K., O’Connor, D.O., Harris, W.H., 2003. Third-body wear of highly cross-linked polyethylene in a hip simulator. The Journal of Arthroplasty 18(5), 553561.

Dowling, J., JR, A., Dowson, D., J, C., 1978 The characteristics of acetabular cups worn in the human body. Journal of Bone \& Joint Surgery, British Volume 60-B(3), 375-382.

Fisher, J., Hu, X.Q., Tipper, J.L., Stewart, T.D., Williams, S., Stone, M.H., Davies, C., Hatto, P., Bolton, J., Riley, M., Hardaker, C., Isaac, G.H., Berry, G., Ingham, E., 2002. An in vitro study of the reduction in wear of metal-on-metal hip prostheses using surface-engineered femoral heads. Proceedings of the Institution of Mechanical Engineers, Part H: Journal of Engineering in Medicine 216(4), 219-230. 
Garellick, G., Kärrholm, J., Rogmark, C., Herberts, P. (2011). Swedish Hip Arthroplasty Register Annual Report 2010 (pp. 1-121).

Harman, M.K., Banks, S.A., Hodge, W.A., 1997. Wear analysis of a retrieved hip implant with titanium nitride coating. The Journal of Arthroplasty 12(8), 938-945.

Ingham, E., Fisher, J., 2005. The role of macrophages in osteolysis of total joint replacement. Biomaterials 26(11), 1271-1286.

Laarz, E., Zhmud, B.V., Bergström, L., 2000. Dissolution and Deagglomeration of Silicon Nitride in Aqueous Medium. Journal of the American Ceramic Society 83(10), 2394-2400.

Lappalainen, R., Anttila, A., Heinonen, H., 1998. Diamond Coated Total Hip Replacements. Clinical Orthopaedics and Related Research 352, 118-127.

Lappalainen, R., Santavirta, S.S., 2005. Potential of Coatings in Total Hip Replacement. Clinical Orthopaedics and Related Research 430, 72-79.

Leyland, A., Matthews, A., 2000. On the significance of the H/E ratio in wear control: a nanocomposite coating approach to optimised tribological behaviour. Wear 246(1-2), 1-11.

Mazzocchi, M., Bellosi, A., 2008. On the possibility of silicon nitride as a ceramic for structural orthopaedic implants. Part I: processing, microstructure, mechanical properties, cytotoxicity. Journal of Materials Science: Materials in Medicine 19(8), 2881-2887.

Mazzocchi, M., Gardini, D., Traverso, P., Faga, M., Bellosi, A., 2008. On the possibility of silicon nitride as a ceramic for structural orthopaedic implants. Part II: chemical stability and wear resistance in body environment. Journal of Materials Science: Materials in Medicine 19(8), 2889-2901.

Oliver, W.C., Pharr, G.M., 1992. An improved technique for determining hardness and elastic modulus using load and displacement sensing indentation experiments. Journal of Materials Research 7, 1564-1583.

Olofsson, J., Pettersson, M., Teuscher, N., Heilmann, A., Larsson, K., Grandfield, K., Persson, C., Jacobson, S., Engqvist, H., 2012. Fabrication and evaluation of $\mathrm{Si}_{\mathrm{x}} \mathrm{N}_{\mathrm{y}}$ coatings for total joint replacements. Journal of Materials Science: Materials in Medicine 23(8), 1879-1889.

Pappas, M.J., Makris, G., Buechel, F.F., 1995. Titanium Nitride Ceramic Film Against Polyethylene: A 48 Million Cycle Wear Test. Clinical Orthopaedics and Related Research 317, 64-70.

Pusch, C., Hoche, H., Berger, C., Riedel, R., Ionescu, E., Klein, A., 2011. Influence of the PVD sputtering method on structural characteristics of SiCN-coatings - Comparison of RF, DC and HiPIMS sputtering and target configurations. Surface and Coatings Technology 205, Supplement 2, S119-S123.

Riley, F.L., 2000. Silicon Nitride and Related Materials. Journal of the American Ceramic Society 83(2), 245-265.

Saikko, V., Calonius, O., Keränen, J., 2001. Effect of counterface roughness on the wear of conventional and crosslinked ultrahigh molecular weight polyethylene studied with a multidirectional motion pin-on-disk device. Journal of Biomedical Materials Research 57(4), 506512.

Sarakinos, K., Alami, J., Konstantinidis, S., 2010. High power pulsed magnetron sputtering: A review on scientific and engineering state of the art. Surface and Coatings Technology 204(11), 16611684.

Sargeant, A., Goswami, T., 2007. Hip implants - Paper VI - Ion concentrations. Materials \&amp; Design 28(1), 155-171.

Shi, Z., Wang, Y., Du, C., Huang, N., Wang, L., Ning, C., 2011. The structure, surface topography and mechanical properties of Si-C-N films fabricated by $\mathrm{RF}$ and $\mathrm{DC}$ magnetron sputtering. Applied Surface Science 258(4), 1328-1336.

Shi, Z., Wang, Y., Du, C., Huang, N., Wang, L., Ning, C., 2012. Silicon nitride films for the protective functional coating: Blood compatibility and biomechanical property study. Journal of the Mechanical Behavior of Biomedical Materials 16, 9-20.

Sonny Bal, B., Khandkar, A., Lakshminarayanan, R., Clarke, I., Hoffman, A.A., Rahaman, M.N., 2008. Testing of silicon nitride ceramic bearings for total hip arthroplasty. Journal of Biomedical Materials Research Part B: Applied Biomaterials 87B(2), 447-454. 
Sonny Bal, B., Khandkar, A., Lakshminarayanan, R., Clarke, I., Hoffman, A.A., Rahaman, M.N., 2009. Fabrication and Testing of Silicon Nitride Bearings in Total Hip Arthroplasty: Winner of the 2007 "HAP” PAUL Award. The Journal of Arthroplasty 24(1), 110-116.

Teresa Raimondi, M., Pietrabissa, R., 2000. The in-vivo wear performance of prosthetic femoral heads with titanium nitride coating. Biomaterials 21(9), 907-913.

Walmsley, B.A., Yinong, L., Xiao Zhi, H., Bush, M.B., Dell, J.M., Faraone, L., 2007. Poisson's Ratio of Low-Temperature PECVD Silicon Nitride Thin Films. Microelectromechanical Systems, Journal of 16(3), 622-627.

Wang, A., Essner, A.P., 2001. Three-body wear of UHMWPE acetabular cups by PMMA particles against CoCr, alumina and zirconia heads in a hip joint simulator. Wear 250(1-12), 212-216.

Williams, S., Tipper, J.L., Ingham, E., Stone, M.H., Fisher, J., 2003. In vitro analysis of the wear, wear debris and biological activity of surface-engineered coatings for use in metal-on-metal total hip replacements. Proceedings of the Institution of Mechanical Engineers, Part H: Journal of Engineering in Medicine 217(3), 155-163.

Yen, S.K., Guo, M.J., Zan, H.Z., 2001. Characterization of electrolytic ZrO2 coating on Co-Cr-Mo implant alloys of hip prosthesis. Biomaterials 22(2), 125-133.

Yen, S.K., Hsu, S.W., 2001. Electrolytic Al2O3 coating on co-cr-mo implant alloys of hip prosthesis. Journal of biomedical materials research 54, 412-418. 
Table 1 - Deposition parameters and summary of test results for $S_{x} N_{y}$ and $S_{x} C_{y} N_{z}$ coatings on silicon wafers and CoCr (marked '*'). The high (h) and low (l) substrate temperature corresponds to approx. $430^{\circ} \mathrm{C}$ and $110^{\circ} \mathrm{C}$, respectively. Coatings that failed in the wear test are marked ( $f$ ).

\begin{tabular}{|c|c|c|c|c|c|c|}
\hline $\begin{array}{l}\text { Coating Name } \\
\text { (Si-target power }[\mathrm{kW}] / \\
\text { C-target power }[\mathrm{kW}] / \text { Temp.) }\end{array}$ & $\begin{array}{r}\text { C content } \\
\text { by EDS } \\
\text { [ at. \%] }\end{array}$ & $\mathrm{H} / \mathrm{E}$ ratio & $\begin{array}{r}\text { Cohesive faliure }\left(\mathrm{L}_{\mathrm{C} 1}\right) \\
\pm \mathrm{SD} \\
{[\mathrm{mN}]}\end{array}$ & 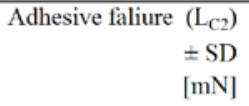 & $\begin{array}{r}\text { Specific wear rate } \\
(1 \mathrm{~N}, \mathrm{n}=1000) \\
{\left[\mathrm{mm}^{3} / \mathrm{N} \mathrm{m}\right]}\end{array}$ & $\begin{array}{r}\text { Specific wear rate } \\
(1 \mathrm{~N}, \mathrm{n}=10000) \\
{\left[\mathrm{mm}^{3} / \mathrm{N} \mathrm{m}\right]}\end{array}$ \\
\hline $\mathrm{SiN}(1 /-/ l)$ & 1 & 0.100 & - & $214 \pm 12$ & $\mathrm{n} / \mathrm{a}$ & $1.3 \cdot 10^{-7}$ \\
\hline $\operatorname{SiN}(2 /-/ l)$ & 2 & 0.087 & - & $260 \pm 15$ & $\mathrm{n} / \mathrm{a}$ & $2.2 \cdot 10^{-7}$ \\
\hline $\operatorname{SiN}(3 /-/ l)$ & 1 & 0.086 & - & no rupture & $\mathrm{n} / \mathrm{a}$ & $2.3 \cdot 10^{-7}$ \\
\hline $\mathrm{SiN}(4 /-/ l)$ & 0 & 0.086 & - & no rupture & $\mathrm{n} / \mathrm{a}$ & $240 \cdot 10^{-7}$ \\
\hline $\operatorname{SiN}(2 /-/ h)$ & 1 & 0.093 & - & $265 \pm 8$ & $\mathrm{n} / \mathrm{a}$ & $2.1 \cdot 10^{-7}$ \\
\hline $\operatorname{SiN}(3 /-/ h)$ & 1 & 0.091 & - & no rupture & $\mathrm{n} / \mathrm{a}$ & $4.8 \cdot 10^{-7}$ \\
\hline $\mathrm{SiCN}(4 / 0.5 / l)$ & 6 & 0.081 & $68 \pm 6$ & $85 \pm 5$ & f & $\mathrm{n} / \mathrm{a}$ \\
\hline $\operatorname{SiCN}(4 / 0.5 / l)^{*}$ & 8 & 0.075 & $26 \pm 2$ & $36 \pm 5$ & $\mathrm{n} / \mathrm{a}$ & $\mathrm{n} / \mathrm{a}$ \\
\hline $\mathrm{SiCN}(4 / 0.7 / l)$ & 9 & 0.078 & $55 \pm 2$ & $81 \pm 7$ & f & $\mathrm{n} / \mathrm{a}$ \\
\hline $\operatorname{SiCN}(4 / 0.7 / /)^{*}$ & 9 & 0.080 & $20 \pm 3$ & $33 \pm 4$ & $\mathrm{n} / \mathrm{a}$ & $\mathrm{n} / \mathrm{a}$ \\
\hline $\mathrm{SiCN}(4 / 1.4 / l)$ & 14 & 0.083 & $65 \pm 7$ & $83 \pm 8$ & f & $\mathrm{n} / \mathrm{a}$ \\
\hline $\operatorname{SiCN}(1 / 0.7 / l)$ & 23 & 0.072 & $39 \pm 6$ & $46 \pm 3$ & $130 \cdot 10^{-7}$ & $\mathrm{n} / \mathrm{a}$ \\
\hline $\operatorname{SiCN}(1 / 1.0 / l)$ & 30 & 0.074 & $42 \pm 2$ & $52 \pm 8$ & $410 \cdot 10^{-7}$ & $\mathrm{n} / \mathrm{a}$ \\
\hline $\mathrm{SiCN}(1 / 1.4 / l)$ & 35 & 0.072 & $36 \pm 2$ & $42 \pm 1$ & $100 \cdot 10^{-7}$ & $\mathrm{n} / \mathrm{a}$ \\
\hline $\operatorname{SiCN}(4 / 0.5 / h)$ & 6 & 0.088 & $68 \pm 6$ & $80 \pm 4$ & f & $\mathrm{n} / \mathrm{a}$ \\
\hline $\operatorname{SiCN}(4 / 0.5 / h)^{*}$ & 8 & 0.078 & $35 \pm 3$ & $67 \pm 5$ & $\mathrm{n} / \mathrm{a}$ & $\mathrm{n} / \mathrm{a}$ \\
\hline $\operatorname{SiCN}(4 / 0.7 / h)$ & 9 & 0.084 & $77 \pm 3$ & $95 \pm 5$ & f & $\mathrm{n} / \mathrm{a}$ \\
\hline $\operatorname{SiCN}(4 / 1.4 / h)$ & 15 & 0.089 & $68 \pm 5$ & $86 \pm 2$ & f & $\mathrm{n} / \mathrm{a}$ \\
\hline $\operatorname{SiCN}(1 / 0.7 / h)$ & 22 & 0.080 & $86 \pm 9$ & $105 \pm 15$ & $f$ & $\mathrm{n} / \mathrm{a}$ \\
\hline $\operatorname{SiCN}(1 / 1.0 / h)$ & 29 & 0.079 & $62 \pm 4$ & $76 \pm 2$ & $110 \cdot 10^{-7}$ & $\mathrm{n} / \mathrm{a}$ \\
\hline $\mathrm{Si}_{3} \mathrm{~N}_{4}$ & $\mathrm{n} / \mathrm{a}$ & 0.035 & $n / a$ & $\mathrm{n} / \mathrm{a}$ & $\mathrm{n} / \mathrm{a}$ & $1.0 \cdot 10^{-7}$ \\
\hline $\mathrm{CoCr}$ & $\mathrm{n} / \mathrm{a}$ & 0.078 & $n / a$ & $\mathrm{n} / \mathrm{a}$ & $\mathrm{n} / \mathrm{a}$ & $60 \cdot 10^{-7}$ \\
\hline
\end{tabular}




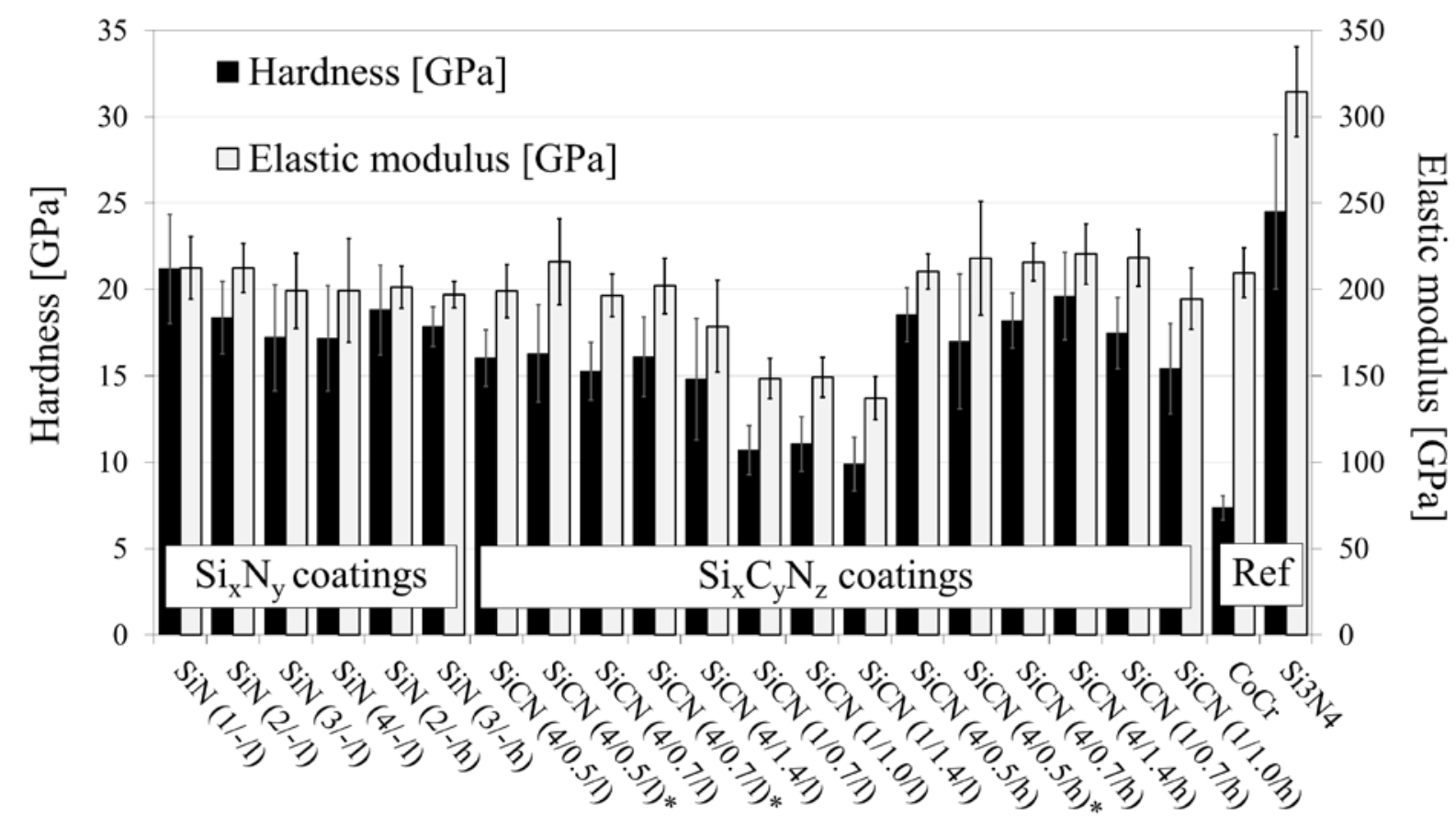

Fig. 1 - Hardness and elastic modulus with indicate standard deviation for $\mathrm{Si}_{x} N_{y}$ and $\mathrm{Si}_{x} \mathrm{C}_{y} N_{z}$ coatings on Si wafers and on CoCr (marked '*') as well as the two reference bulk materials, CoCr and $\mathrm{Si}_{3} \mathrm{~N}_{4}$. 


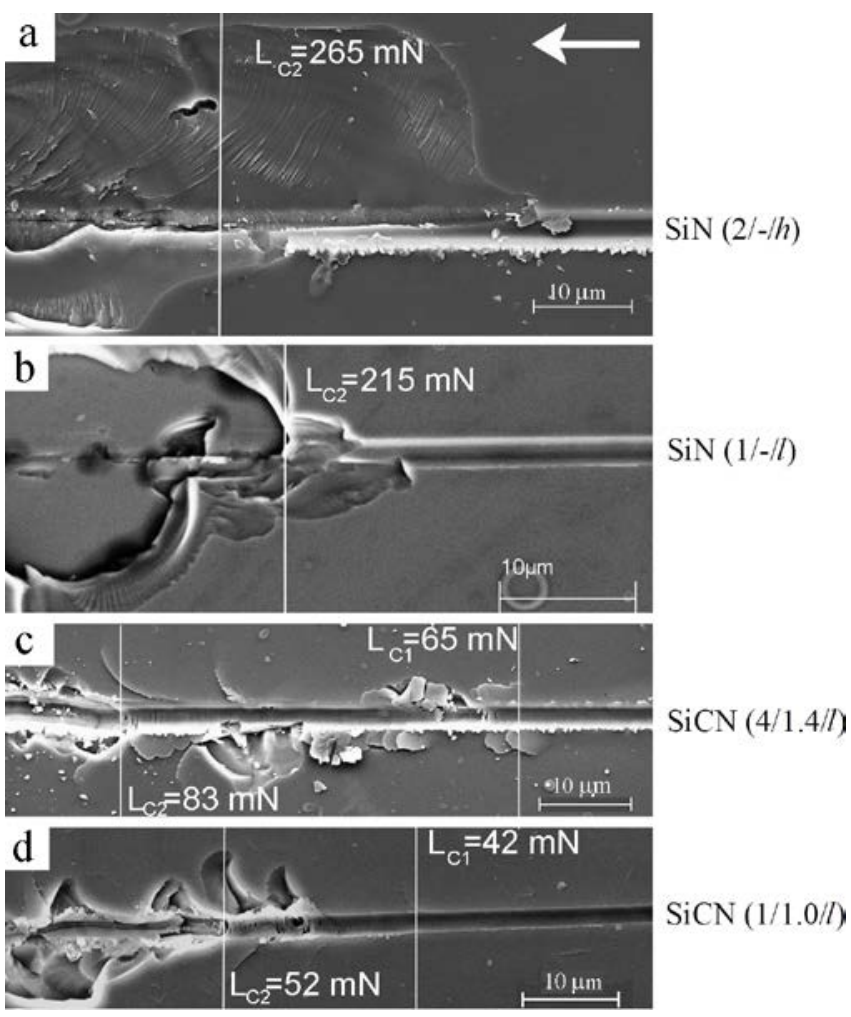

Fig. 2 - Scratch test of coatings deposited on silicon wafers for a) $\operatorname{Si}_{x} N_{y}$ coating $\left.\operatorname{SiN}(2 /-/ h), b\right) \mathrm{Si}_{x} N_{y}$ coating SiN (1/-/l), c) $\operatorname{Si}_{x} C_{y} N_{z}$ coating SiCN (4/1.4/l), deposited with a Si-target power of $4 \mathrm{~kW}$, and d) $\mathrm{Si}_{x} C_{y} N_{z}$ coating $\mathrm{SiCN}(1 / 1.0 / \mathrm{l})$, deposited at $1 \mathrm{~kW}$. The arrow indicates the direction of scratching. 


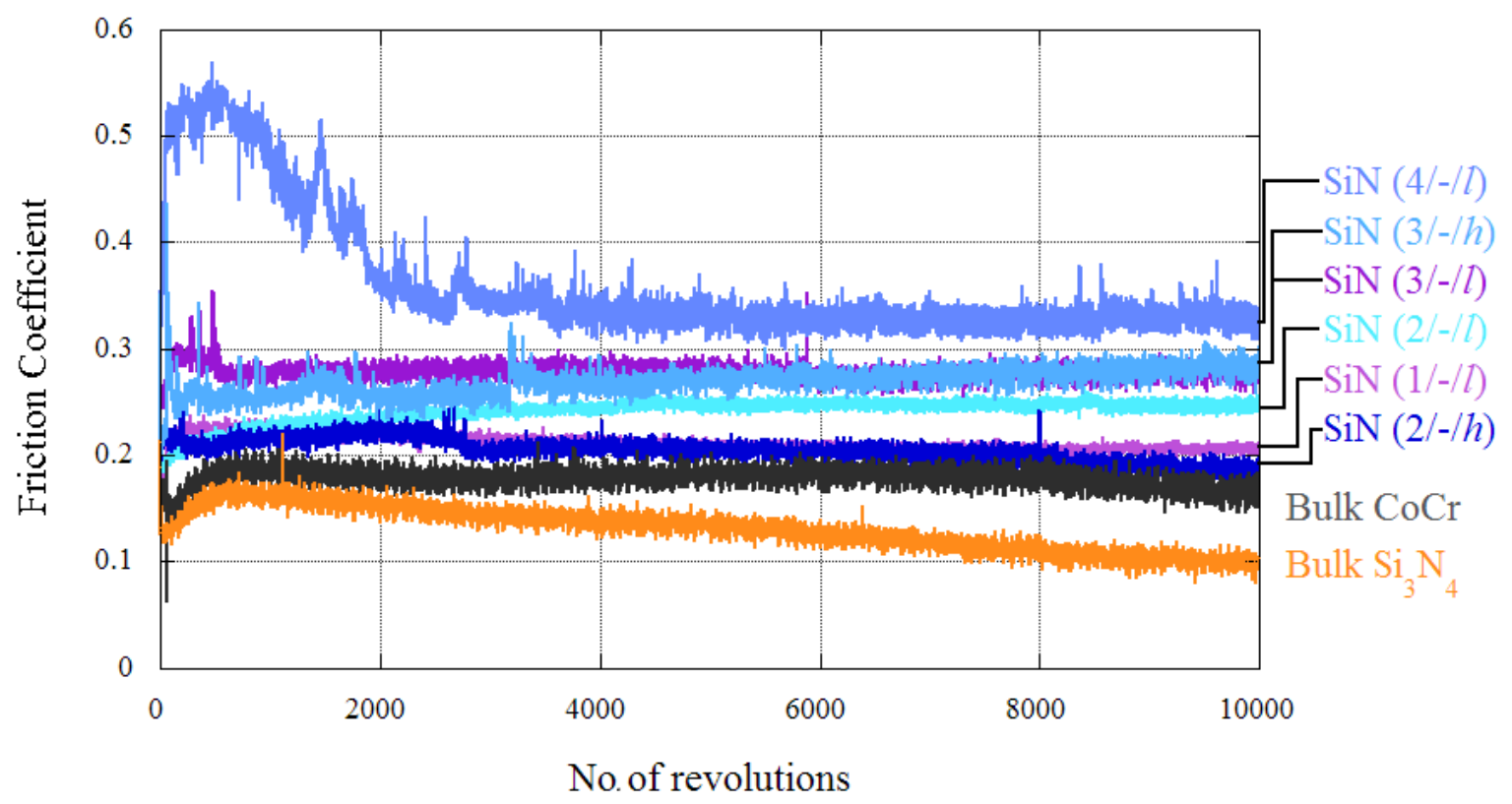

Fig. 3 - Friction coefficient versus number of revolutions from ball-on-disc test for tests run 10000 cycles for $\mathrm{Si}_{x} N_{y}$ coatings and the reference materials. 


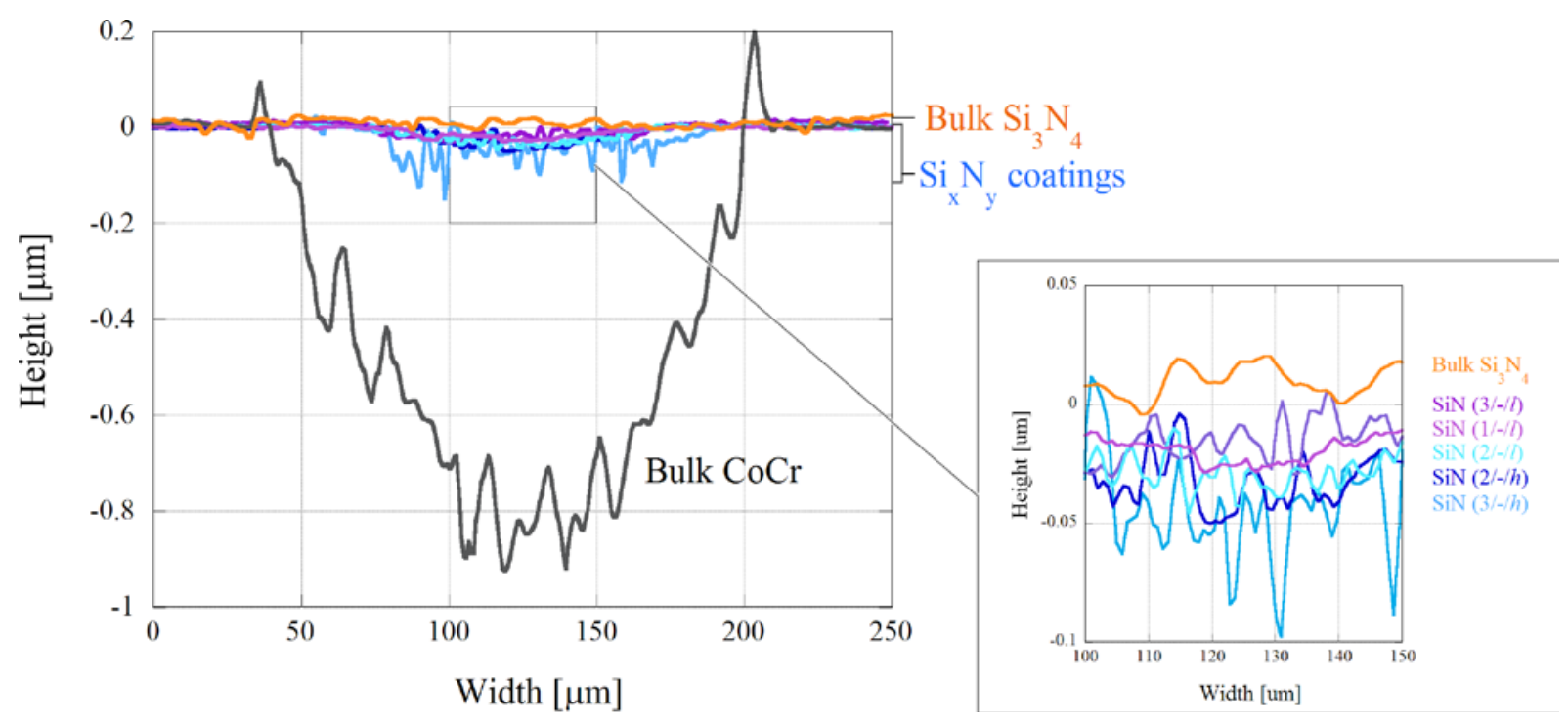

Fig. 4 - Wear track cross-section profiles for all $\mathrm{Si}_{x} N_{y}$ coatings, except SiN (4/-/l), plotted with CoCr and sintered $\mathrm{Si}_{3} \mathrm{~N}_{4}$ as reference. Note the scale difference of the $x$ and $y$ axes. 
$\begin{array}{lll}\text { a) Bulk } \mathrm{Si}_{3} \mathrm{~N}_{4} & \text { b) Bulk CoCr } & \text { c) } \mathrm{Si}_{\mathrm{x}} \mathrm{N}_{\mathrm{y}} \text { coating }\end{array}$ $\mathrm{SiN}(2 /-/ h)$
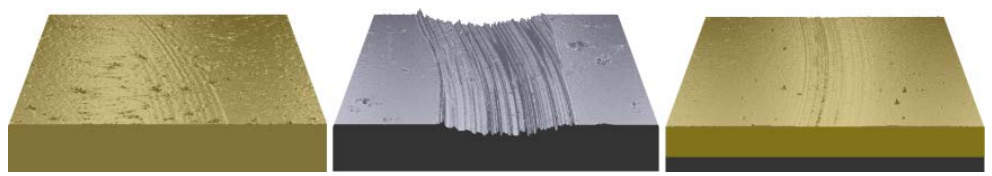

Fig. 5 - Samples with wear tracks after 10000 revolutions in ball-on-disc test. The sample size is 362 $\mu m$ (width) $\times 452 \mu m$ (depth) $\times 3 \mu \mathrm{m}$ (thickness). 